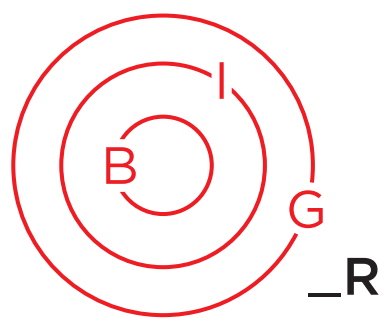

ESSAY

SPECIAL ISSUE

\title{
West Bank-Israel Wall During COVID-19: Migrant Labour Upends Border Function
}

\author{
Walid Habbas*
}

\begin{abstract}
The function of the West Bank-Israeli separation barrier, designed to segregate Palestinians away from Israeli territory, was subverted by the COVID-19 crisis. For the first time, the barrier locked West Bank Palestinians inside Israel. For a two-month period, construction workers from the West Bank were sequestered at work sites in Israel to reduce movement of people between the territories while also minimizing economic losses. This turn of events illustrates the ad hoc economic interests underlying Israeli security policy toward the West Bank.
\end{abstract}

\section{Introduction}

Since 1967, Israeli colonial rule governed Palestinians in the West Bank according to two principles. Demographically, Israel managed Palestinians as non-citizen subjects and governed them through a variety of exclusionary policies aimed at separating them from Israeli citizens (Gordon 2008). Economically, successive regulations rendered the Palestinian

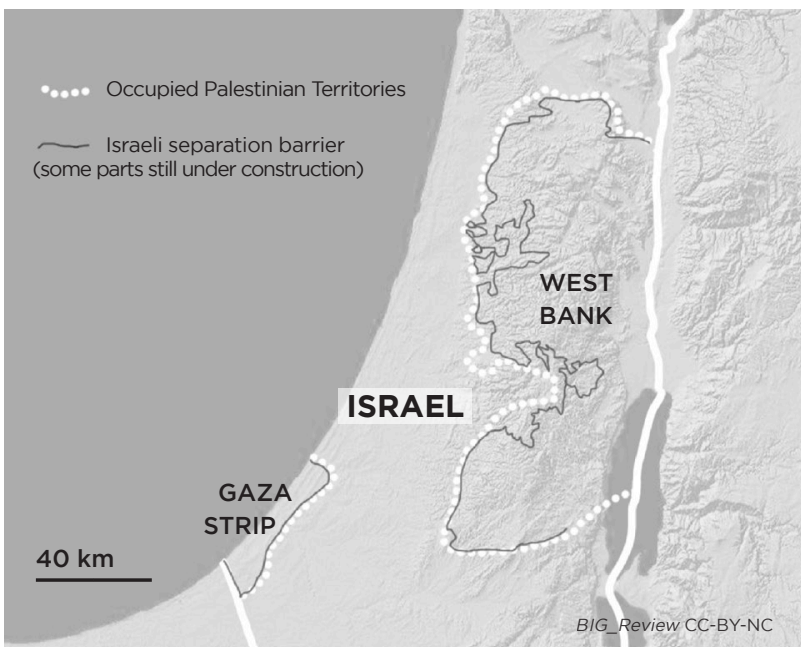

economy dependent on, and integrated into, the much more advanced Israeli economy (Taghdisi-Rad 2014). One of the core features of dependency is low-wage Palestinian labour that, from the outset, commuted daily to workplaces in Israel. The practical combination between population-exclusion and economy-inclusion shifted throughout the years, and since 2005 it was organized around the West Bank-Israeli separation barrier, commonly known as the Segregation Wall or just 'the Wall', which was constructed primarily between 2002 and 2005.1 Since then, Palestinian labour commuting from the West Bank into Israel has followed a cross-border mechanism through designated crossing gates. Yet, Israeli border policies were keen on organizing Palestinian employment inside Israel during the day and locking them out at night in their residential areas behind the Wall. The breakout of COVID-19 upended the segregation function of the Wall and, for the first time, Israel permitted Palestinian labour migrants to reside inside Israel for an extended period. By exploring the factors motivating this extraordinary policy alteration, this essay challenges the general understanding according to which the Israeli military and other governmental agencies exclusively determine the functioning of the Segregation Wall

\footnotetext{
* Walid Habbas, PhD Candidate, Department of Sociology and Anthropology, The Hebrew University of Jerusalem. Email: walidhabbas1980@gmail.com Twitter: @walidhabbas
} 
(Braverman 2011; Farsakh 2005a). The interpretation offered here highlights the West Bank-Israel barrier as a site for state-society interactions and emphasizes the economic interests of Israeli private sectors affecting border regulations.

\section{Palestinian Migrant Labour Across the Wall}

In 1972, the Israeli military issued a general exit permit that allowed Palestinians in the occupied West Bank to cross freely into Israel. Consequently, labourers began commuting daily to Israeli work sites, turning labour migration into a central feature of the Palestinian-Israeli economic relationship (Farsakh 2005b). In the period between 1972 and 1991, labour crossing was relatively fluid due to the absence of physical borders between the occupied West Bank and Israel. However, migration was organized only in the daytime and labourers were never permitted to stay overnight inside Israel (Bornstein 2001). A primary Israeli governing principle that organized Palestinian low-wage labour migration was a policy of actively preventing Palestinians from changing their residency status. From the Israeli perspective, assimilating more Arab Palestinians inside Israel is considered a major demographic threat that could jeopardize the "Judaism" of the Israeli state (Lustick 2019).

Three significant political developments radically changed the crossing patterns of Palestinians that were much sought-after as a labour force while at the same time very undesired as residents. First, the outbreak of the First Palestinian Intifada (1987-1991) led to the cancellation of the general permit in January 1991; as a result, each Palestinian labourer was compelled to acquire an individual working permit to cross into Israel (Berda 2017). The second development was the introduction of the Oslo peace process in 1993, which resulted in recognition of highly-populated Palestinian areas as semi-autonomous territories under the administration of newly created Palestinian Authority. ${ }^{2}$ Consequently, Palestinian labour migration resembled frontier commuting between two distinct economies based on a two-state model. The third event is the escalation of violent conflict during the Second Palestinian Intifada (2000-2004), which radically changed Israel's colonial mode of governing Palestinians. Territory designated for Palestinian self-rule became physically segregated, and severe restraints were imposed on Palestinian mobility by Israeli security forces. During this period, Israel institutionalized a border regime that entails a network of military checkpoints, road closures, electric fences and iron gates, as well as massive concrete walls. According to Farsakh (2005a), Palestinian self-rule localities became de facto labour reserves or "Bantustans". Palestinian workers living in these areas became structurally reliant on the Israeli labour market. Still, they could not commute to work without a permit issued by the Israeli military authorities.
These arrangements brought about substantial changes in the mode of Palestinian labour migration. The separation barrier, which is over 700 kilometres long, portions of which are concrete and up to eight meters high, includes designated crossing points through which Palestinian daily migration is allowed to commute after waiting in long and burdensome queues (B'Tselem 2017). The crossing points are connected to the permit system that checks the alignment of each crossing worker with Israeli security as well as economic and political considerations (Braverman 2011). During Shabbat (the Jewish weekend), Israeli holidays and various security events, closing the crossing points becomes an effective incarceration tool, and Palestinian labourers are effectively locked inside their "Bantustans".

There is a general agreement that the Segregation Wall consistently reshapes the scope of Palestinian labour migration through its blocking and sorting function (Taghdisi-Rad 2014; Farsakh 2005a). ${ }^{3}$ However, once it was constructed as a colonial interface to organize the inflow of labour, the Wall became a potential site for state-society interactions, an issue that is mostly neglected in the available literature. The outbreak of COVID-19 in March 2020 constitutes an illustrative event that highlights the role of Israeli economic actors in negotiating and transforming the segregation policies that are largely conceived as an Israeli security affair.

\section{Upending Segregation, Saving the Economy}

On the eve of the COVID-19 breakout, there were about 130,000 Palestinian migrants (about 18 percent of the West Bank work force) commuting daily to Israel, including 64 percent that work in construction (PCBS 2020). It is believed that official statistics underestimate the actual size of Palestinian migration, due to the existence undocumented labour and labour smuggling (Parizot 2012). Kamel Shachra, a prominent real estate entrepreneur in Israel, claims that the actual number of Palestinian construction workers alone likely exceeds 100,000 (author interview with Kamel Shachra, Israeli construction entrepreneur, Jerusalem, May 20, 2020). These labourers are employed in addition to 205,000 Israeli workers and about 15,000 foreign workers (BenReuven 2020).

Although Israeli labour was available to substitute for Palestinian workers in the event of a sudden and prolonged border closure, Palestinian workers proved to be a critical socioeconomic factor in the Israeli economy. Not only do they constitute low-wage yet highly-experienced labour, but also, as non-citizens, they are not organized in labour unions. As a vulnerable population with little opportunity, they are willing to work under challenging conditions and relinquish labour rights (Bartram 1998). 
When the West Bank-Israel border closure became a high priority on the Israeli state's agenda to curb the spread of the virus, the construction sector stood to be profoundly affected. In February 2020, this sector, including infrastructure, was responsible for 11 to 12 percent of Israel's GDP and was financed by USD 284 billion of credit from Israeli banks and other financial institutions (Ben-Reuven 2020). Uncertainty regarding the duration of the closure elevated the risk of a shock to the Israeli construction sector that could drag into other vital economic sectors (Avigal 2020), potentially bringing the entire Israeli economy to the verge of collapse.

Emergency measures prepared by the Israeli Ministry of Health were intended to be enforced in the first two weeks of March 2020 and entailed shutting down borders. This meant that Palestinian workers would remain in Palestinian areas behind the Wall and beyond the scope of Israeli emergency health measures. The fate of Palestinian labour in critical sectors, such as construction, was an important factor that postponed this decision. The Israeli Builders Association reflected on the imminent border shutdown by declaring:

We in the association are making strenuous efforts to exclude the construction industry from the border restrictions... so that the industry will not be harmed. One of the actions taken is to allow workers from Judea and Samaria [the Israeli name of the occupied West Bank] to enter work in Israel continuously"(ACB 2020).

When the Government of Israel shut down land borders with Jordan, Egypt and the West Bank, beginning on March 18, 2020, it immediately exempted "non-nationals" whose "centre of life" was Israel (MFA 2020). This exemption implicitly referred to Palestinian construction labour and was quickly institutionalized due to the role exerted by Israeli construction entrepreneurs (author interview, Shachra, 2020). It should be emphasized that the exemption did not permit Palestinian construction labour to continue commuting on a daily basis, but rather called upon them to be segregated inside Israel instead of in their homes beyond the Wall. On March 18, 2020, about 60,000 Palestinians entered Israel and resided in construction sites for a duration of 60 days before the first COVID-19 wave was curbed leading to the lifting of the border closure.

Subverting the function of the Segregation Wall, which was induced by the classification of the construction industry as critical, demanded three innovations. First, in order to overcome the health risk of accommodating "non-citizens" without subjecting them to 14 days of quarantine, the Israeli Builders Association proposed to divide the workers into groups of capsules. Each capsule contained a maximum of ten workers and was treated as one body during the process of crossing into Israel, and Israeli construction companies pledged that each capsule would remain entirely on the construction site (author interview with Isaac Gurvich, deputy director-general of manpower in the Israeli Builders Association, Tel Aviv, July 21, 2020). Workers were tested for virus and were handed hand sanitizers at the beginning of each working day. Second, construction companies were required by the Israeli government to provide three meals, modest sleeping furniture and sometimes rental of apartments in order to accommodate the Palestinian workers. However, the workers were asked to increase their working hours without receiving additional wages to compensate for the new accommodation expenses (author interview, Shachra, 2020). Third, Israeli security agencies imposed additional regulations to guarantee that the Palestinian labourers remained segregated inside Israel. They were obliged to download a tracing application on their mobile devices, and Israeli security officers and patrols paid unexpected visits to construction sites to verify and ensure their segregation (Who Profits 2020).

On June 28, 2020, during the second coronavirus wave, Israel permitted Palestinian workers once again to remain overnight in Israel, this time for 35 consecutive days. However, when Israel declared the shutdown of borders during the third wave on September 18, the Palestinian workers were exempted again, but this time instead of overnighting in Israel, they were allowed to continue crossing on a daily basis. Until the coronavirus is totally contained, new unforeseeable alterations in the Wall function should be expected.

\section{Conclusion}

Since its construction primarily in 2002-2005, the West Bank-Israel Segregation Wall operated as a security apparatus to ensure that workers reside in the West Bank although the centre of their economic life was in Israel. At the outbreak of COVID-19, the interests of the Israeli construction sector, threatened by the shutdown of borders and the loss of the low-wage Palestinian labour force, upended the segregation function of the border by accommodating Palestinian labour inside Israel during the border shutdown, even allowing regular passage at a time when the country's international borders were sealed. Although the Wall remains a colonial imposition with far-reaching geopolitical consequences, the case of Palestinian construction labour during the COVID-19 pandemic reveals the role of non-state actors in negotiating and reconstructing the Wall's function. However, this did not bring about an absolute solution to the potential health risk produced by the continuous daily interactions between Palestinians and Israelis. While the West Bank-Israeli wall is a highly securitized border, it should be emphasized that it is not a barrier that separates neatly between two states. Since Israelis settlers also reside in the West Bank, the border might be better understood as a segregating edifice used to monitor 
the crossings of Palestinians while Israelis on both sides can still move freely. Whether Palestinian workers are segregated inside the West Bank (the pre-coronavirus arrangements), or inside Israel (during the breakout of coronavirus), Palestinian and Israeli populations could still interact on daily bases at least in parts of the West Bank. Therefore, the hardening of the Wall during the pandemic ended most Palestinian border-crossings, yet failed to totally sever daily Palestinian-Israeli interactions. The one-state reality produced after decades of Israeli settlement expansion in the occupied West Bank (Azoulay and Ophir 2013) renders the in-between borders an ineffective policy to contain the virus, yet an effective surveillance tool to monitor Palestinian mobility (Zureik 2011).

\section{Notes}

1 In 2004, the International Court of Justice stated that the West Bank-Israel barrier violated international law for extending into Palestinian territory from the Green Line (the 1949 Armistice line separating Israel from the West Bank and constituting Israel's internationally recognized border). The barrier (712 kilometres) is twice as long as the Green line (320 kilometres) and about 85 percent of its meandering route weaves through large portions of the occupied West Bank, annexing de facto Israeli settlements and fragmenting the Palestinian communities. In 2017, about 65 percent of the wall has been constructed either as a concrete wall or an electronic fence (B'Tselem 2017).

2 This did not bring Israeli colonial rule to an end. Palestinian semi-autonomous territories (known as Area A and B) are non-continuous enclaves scattered throughout the West Bank (together comprising 40 percent of the West Bank), non-militarized, and regularly subject to Israeli military closures and incursions.

3 This essay engages with critical literature on the Israeli Occupation and the function of borders in the West Bank that envision a colonial paradigm. For other perspectives please refer to Jones (2009).

\section{Works Cited}

ACB. 2020. "Accommodating of Palestinian workers during the Corona crisis". Israeli Builders Association (March 10). Available: http://acb.org.il/ /ה-רבשמ-תפוקתב-םיאניתשלפ-םידבוע-תנלה

Avigal, Mair. 2020. "Continued Closure in Judea and SamariaSevere Damage to the Construction Industry". Calcalist (March 13). Available: https://www.calcalist.co.il/local/ articles/0,7340,L-3800633,00.html

Azoulay, Ariella, and Adi Ophir. 2013. The One-State Condition: Occupation and Democracy in Israel/Palestine. Stanford, California: Stanford University Press.

Bartram, David V. 1998. "Foreign Workers in Israel: History and Theory". International Migration Review 32(2): 303-25. http://www.jstor.org/stable/10.2307/2547185
Ben-Reuven, Eyal. 2020. "Position paper on the protection of workers in the construction industry against the coronavirus". Available: https://fs.knesset.govil/23/Committees/23 cs_bg_568164.pdf

Berda, Yael. 2017. Living Emergency: Israel's Permit Regime in the Occupied West Bank. Stanford, California: Stanford University Press.

Bornstein, Avram S. 2001. "Border Enforcement in Daily Life: Palestinian Day Laborers and Entrepreneurs Crossing the Green Line". Human Organization 60(3): 298-307. https:// doi.org/10.17730/humo.60.3.bqqwen2r01h6t8aq

Braverman, Irus. 2011. "Civilized Borders: A Study of Israel's New Crossing Administration" Antipode 43(2): 264-95. https://doi.org/10.1111/j.1467-8330.2010.00773.x

B'Tselem. 2017. "The Separation Barrier”. Jerusalem: B'Tselem - The Israeli Information Center for Human Rights in the Occupied Territories. Available: https://www.btselem.org/ separation_barrier

Farsakh, Leila. 2005a. "Independence, Cantons, or Bantustans: Whither the Palestinian State?" Middle East Journal 59(2): 230-45. https://doi.org/10.3751/59.2.13

2005b. Labour Migration and the Palestinian State: The Political Economy of Palestinian Labour Flows to Israel. London: Routledge.

Gordon, Neve. 2008. Israel's Occupation. Berkeley: University of California Press.

Jones, Clive. 2009. "The Writing on the Wall: Israel, the Security Barrier and the Future of Zionism". Mediterranean Politics 14(1): 3-20. https://doi.org/10.1080/13629390902747335

Lustick, Ian S. 2019. "The Red Thread of Israel's 'Demographic Problem"'. Middle East Policy 26(1): 141-49. https://doi. org/10.1111/mepo.12406

MFA. 2020. "Foreign Nationals Barred from Entering Israel: Population and Migration Authority Update". Israel Ministry of Foreign Affaris. Available: https://mfa.gov.il/ MFA/PressRoom/2020/Pages/Foreign-nationals-barredfrom-entering-Israel-update-19-March-2020.aspx

Parizot, Cédric. 2012. "An Undocumented Economy of Control: Workers, Smugglers and State Authorities in Southern Israel/Palestine" Halshs, no. 007736329: 1-20. Available: https://halshs.archives-ouvertes.fr/halshs-00736329/file/ An_Undocumented_border_economy.pdf

PCBS. 2020. "Palestinian Labour Force Survey: Annual Report: 2019." Ramallah: Palestinian Central Bureau of Statistics.

Taghdisi-Rad, Sahar. 2014. "The Economic Strategies of Occupation: Confining Development and Buying-off Peace." In Mandy Turner and Omar Shweiki (eds.) Decolonizing Palestinian Political Economy: De-Development and Beyond. New York: Palgrave Macmillan. 13-31.

Who Profits. 2020. "Exploited and Essential: Palestinian Labour Under COVID-19." Flash Report. Tel Aviv: Who Profits from the Occupation organization. Available: https://whoprofits. org/wp-content/uploads/2020/06/Exploited-andEssential-Palestinian-Labour-under-Covid-19-2.pdf

Zureik, Elia. 2011. "Colonialism, Surveillance, and Population Control: Israel/Palestine". In Elia Zureik, David Lyon, and Yasmeen Abu-Laban (eds.) Surveillance and Control in Israel/Palestine: Population, Territory, and Power. New York: Routledge. 3-46. 